\title{
Corrosion Inhibitive and Adsorption Behaviour of Methanolic Extracts of Adansonia digitata (Baobab) Fruit Pulp and Seeds for Mild Steel in $1.0 \mathrm{M} \mathrm{H}_{2} \mathrm{SO}_{4}$
}

\author{
"Petro Novert Karungamye ${ }^{1}$, H. C. Ananda Murthy ${ }^{2}$ \\ ${ }^{I}$ (Department of Chemistry, College of Natural and Mathematical Sciences, the University of Dodoma, \\ Tanzania) \\ ${ }_{2}^{2}$ (Department of Chemistry, College of Natural and Mathematical Sciences, the University of Dodoma, \\ Tanzania) \\ Corresponding Author: Petro Novert Karungamye
}

\begin{abstract}
Abstract : Adansonia digitata (Baobab) pulp and seeds extracts have been tested for corrosion inhibition of mild steel in $1.0 \mathrm{M} \mathrm{H}_{2} \mathrm{SO}_{4}$ solution at room temperature. The inhibition efficiency and corrosion rate were studied using gravimetric, polarization and electrochemical impedance spectroscopy (EIS) methods. The surface morphology of MS was studied with scanning electron microscope (SEM). The Results revealed that Adansonia digitata seeds extract (ADSE) was found to be better corrosion inhibitor for mild steel in $\mathrm{H}_{2} \mathrm{SO}_{4}$ than Adansonia digitata pulp extracts (ADPE). Inhibition efficiency was found to be $57.65 \%$ and $68.70 \%$ for ADPE and ADSE respectively. Polarization studies revealed that both ADPE and ADSE act as mixed-type inhibitor. Adsorption isotherm was found using experimental data obtained in weight loss measurements. The absorption of both extracts on the mild steel surface was found to follow Langmuir adsorption isotherm. The surface analysis using scanning electron microscopy (SEM) confirmed both ADPE and ADSE played a significant protective effect on mild steel in $1.0 \mathrm{M} \mathrm{H}_{2} \mathrm{SO}_{4}$ solution. ADPE and ADSE could serve as effective green inhibitors for mild steel corrosion in $1.0 \mathrm{M} \mathrm{H}_{2} \mathrm{SO}_{4}$ solution due to the adsorption of phytoconstituents of extracts.
\end{abstract}

Keywords: Mild steel corrosion, Green inhibitor, Adansonia digitata, EIS, SEM.

\section{INTRODUCTION}

The Mild steel (MS) also known as low carbon steel is an alloy composed of carbon 0.16 to $0.29 \%$ and density of $7.85 \mathrm{~g} / \mathrm{cm}^{3}$ [1]. The properties of MS like easy availability, ease of fabrication, low cost and good tensile strength increase its applicability in industries. However when it comes in contact with acid during acid cleaning, transportation of acid, de-scaling, storage of acids and other chemical processes it suffers from severe corrosion [2]. Acid solutions especially hydrochloric acid and sulfuric acid are normally used in industry for different purposes like cleaning, descaling and pickling of metallic structures [3][4]. These processes are normally accompanied by considerable dissolution of the metal resulting into corrosion [5]. The process of metal dissolution and excess acid consumption during pickling processes can be reduced by addition of corrosion inhibitors in acid [6].

A corrosion inhibitor, is a chemical substance which when added in small quantity in a corrosive media, slows down the rate of corrosion of a metal or a metal alloy without significantly changing the concentration of a corrosive agent [7][8]. Use of inhibitors is one of the most practical methods for protection of metals and alloys against corrosion especially in acid media [9]. Selection of the best inhibitor depends on different factors like type of acid used, concentration of inhibitor, applied temperature, velocity of the solution, presence of dissolved solids, and the type of metal or alloy involved [10]. Synthetic inhibitors have good anticorrosive activity, but most of them are highly toxic to both human beings and environment.The increase in awareness of health and ecological risks caused by synthetic inhibitors has drawn attention in looking for more suitable inhibitors, which are non-toxic and environmental friendly [6].

Different research studies have proved that natural parts of plant origin containing various organic compounds have corrosion inhibitive action [11][12][13][14][15]. This makes the plant extracts and the derived organic species become important for application as an environmentally friendly, renewable, readily available, and acceptable source of corrosion inhibitors [16]. Some of the constituents in plant products include amino acids, alkaloids, tannins and pigments [17]. Compounds having $\pi$-bond and hetero atoms like $\mathrm{P}, \mathrm{N}, \mathrm{S}$ and $\mathrm{O}$ are said to be good inhibitors. The efficiency of a compound as corrosion inhibitor depends on its ability to be adsorbed on the surface of a metal or alloy [18]. 
Adansonia digitata or Baobab plant is shown in figure 1 (commonly known as 'Mbuyu' in Tanzania). It belongs to the family Bombaceae and is known generally as the African baobab [19].

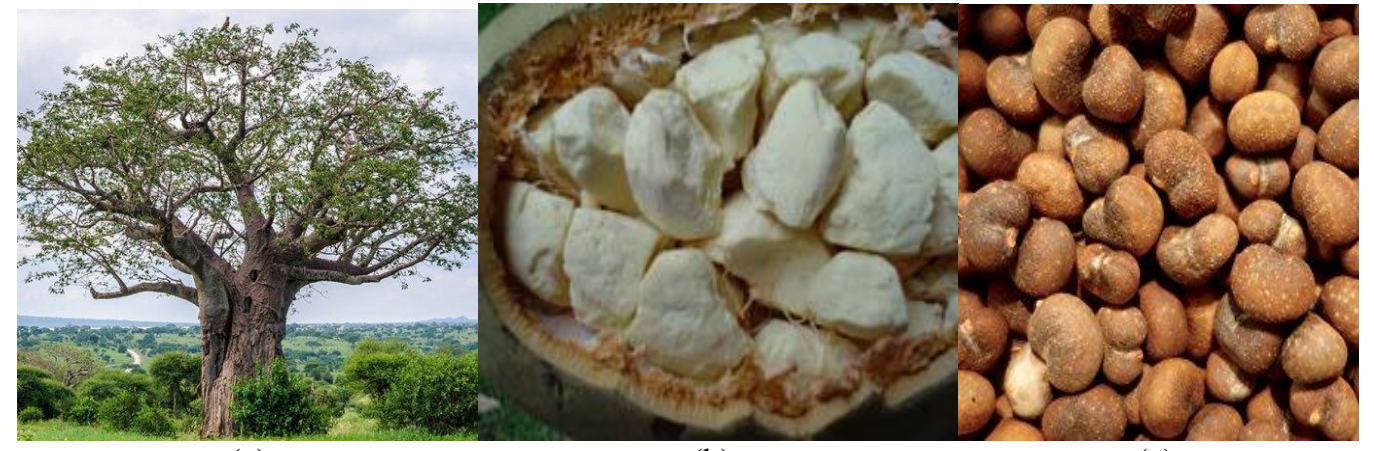

(a)

(c)

Figure 1: Baobab tree (a) fruit pulp (b) and seeds (c)

The composition of fruit pulp is in average of $8.7 \%$ moisture with $2.7 \%$ protein, $0.2 \%$ fat, $73.7 \%$ carbohydrate, $8.9 \%$ fibres and $5.8 \%$ ash while the seeds have moisture $8.1 \%$, protein $33.7 \%$, fat $30.6 \%$, carbohydrates $4.8 \%$, fibres $16.9 \%$ and ash $5.9 \%$ [20]. Phytochemical investigation of different parts of this plant shows the presence of flavonoids, phytosterols, amino acids, fatty acids, vitamins and minerals [21]. The seeds have high percent of amino acids when compared to the other parts of the plant [22]. Methanol extract of the pericarp of the fruits of Adansonia digitata contain the following major compounds; (-)-epicatechin, epicatechin$(4 \beta \rightarrow 8)$-epicatechin, epicatechin- $(4 \beta \rightarrow 6)$-epicatechin, epicatechin- $(2 \beta \rightarrow O \rightarrow 7, \quad 4 \beta \rightarrow 8)$-epicatechin, and epicatechin- $(4 \rightarrow \mathrm{b} 8)$-epicatechin- $(4 \beta \rightarrow 8)$-epicatechin [23].

However, no investigation has been carried out on baobab fruit pulp and seed extracts for their corrosion inhibition properties. So the present work was aimed to investigate the efficiency of methanolic extracts of Adansonia digitata fruit pulp and seeds as green and ecofriendly corrosion inhibitors for MS in $1.0 \mathrm{M}$ $\mathrm{H}_{2} \mathrm{SO}_{4}$ solution by gravimetric, polaristaion, electrochemical impedance and SEM techniques.

\section{EXPERIMENTAL}

\subsection{Materials and sample preparation}

The MS coupons used in this study were prepared from plate of grade JIS G 3132 having the composition (wt. \%) of C (0.18), Si (0.35), Mn (0.60), P (0.040), S (0.040), Cr (0.14) and remaining Fe. For weight loss measurements the MS coupons of dimension $76.2 \mathrm{~mm}$ x $22.23 \mathrm{~mm}$ x $3.18 \mathrm{~mm}$ with a hole drilled 6 $\mathrm{mm}$ from one side were used and for electrochemical studies the square rod of the same material with dimension $10 \mathrm{~mm} \times 10 \mathrm{~mm} \times 30 \mathrm{~mm}$ coated with epoxy resin leaving an exposed area of $1 \mathrm{~cm}^{2}$ was used. For surface analysis using scanning electron microscopy (SEM), the MS coupons of dimension $30 \mathrm{~mm} \times 30 \mathrm{~mm} \times 3 \mathrm{~mm}$ were used. Before each experiment, MS coupons were mechanically abraded with emery papers of grades 600 , 800 and 1000, rinsed in distilled water, degreased in acetone, air dried and stored in desiccators. The corrosive medium was prepared by diluting analytical grade sulphuric acid with distilled water to get $1.0 \mathrm{M} \mathrm{H}_{2} \mathrm{SO}_{4}$ solution.

\subsection{Preparation of plant pulp and seeds extracts}

Dry fruits of Adansonia digitata were manually collected from villages around the University of Dodoma. The fruit pulp was obtained by grinding and sieving to remove the fibers and seeds. After removing the pulp, the seeds were washed properly with running tap water, sun dried, mechanically pressed to extract oil and the residues were ground into powder. Both pulp powder and seeds powder were stored in airtight polythene bags. $500 \mathrm{~g}$ of each of these powders were extracted separately with $2.5 \mathrm{~L}$ of $80 \%(\mathrm{~V} / \mathrm{V})$ aqueous methanol for $24 \mathrm{~h}$ at room temperature. Methanol was selected based on efficiency of extraction when compared to aqueous ethanol. Aqueous methanol is more effective in extraction of polar and moderately polar components from different plant material [24][25]. The residues were removed by double filtration, first with clean textile then with Whatman filter papers. This was followed by concentrating the extracts using warm air evaporator to get the crude extracts [23]. Both Adansonia digitata pulp extract (ADPE) and Adansonia digitata seeds extract (ADSE) were stored in glass bottles for corrosion studies. 


\subsection{Gravimetric method}

Gravimetric (weight loss) experiments were carried out as described by ASTM practice standard G-31. The weighed MS coupons $\left(76.2 \mathrm{~mm} \times 22.23 \mathrm{~mm} \times 3.18 \mathrm{~mm}\right.$ ) were immersed in $200 \mathrm{ml}$ of $1.0 \mathrm{M} \mathrm{H}_{2} \mathrm{SO}_{4}$ acid solutions containing different concentrations of ADSE and ADPE inhibitors for immersion periods of 24h, $48 \mathrm{~h}$ and $72 \mathrm{~h}$ at room temperature according to reported studies [26][27][28][8]. After each exposure time, the coupons were removed from the corrosive media and immersed in $70{ }^{\circ} \mathrm{C}$ mixtures of $200 \mathrm{~g} / \mathrm{L}$ of $\mathrm{NaOH}$ and $20 \mathrm{~g} / \mathrm{L}$ of Zinc dust for 45 minutes as a way to remove the corrosion product from MS surface. The coupons were then cleaned with brush in running tap water and rinsed with distilled water, cleaned in acetone, dried and reweighed. From two identical experiments the mean of weight loss values was used to calculate the surface coverage $(\theta)$, percentage inhibition efficiency (\%IE) and corrosion rate (CR) in millimeters per year (mmpy) using the following formula;

$$
\begin{gathered}
\text { surface coverage }(\theta)=\frac{w_{0}-w_{1}}{w_{o}} \\
\text { Inhibition efficiency }\left(\% \text { IE) }=\frac{w_{0}-w_{1}}{w_{o}} \times 100\right. \\
\text { Corrosion rate }(\rho)=\frac{87.6 \mathrm{~W}}{\rho A t}
\end{gathered}
$$

Where:

$w_{o}=$ Average weight loss without inhibitor

$w_{1}=$ Average weight loss with inhibitor

$w=$ Weight loss $(\mathrm{mg})$

$\rho=$ Density $\left(7.86 \mathrm{gm} / \mathrm{cm}^{3}\right.$ for mild steel $)$

$A=$ Area of the mild steel coupon $\left(\mathrm{cm}^{2}\right)$

$t=$ Time (h)

\subsection{Electrochemical measurements}

Electrochemical studies were conducted in a three-electrode cell assembly consisting of MS square rod with exposed area of $1 \mathrm{~cm}^{2}$ as working electrode, the platinum electrode as an auxiliary (counter) electrode and the saturated calomel electrode as a reference electrode. The Electrochemical measurements were carried out using Autolab Potentiostat / galvanostat model Aut50665 and the data were collected with NOVA 1.11 software. Electrochemical plots were recorded with applied potential $\mathrm{E}=\mathrm{E}_{\mathrm{corr}} \pm 200 \mathrm{mV}$, and a scan rate of 1.0 $\mathrm{mV} \mathrm{s}^{-1}$ [29][30]. Tafel curves were extrapolated to obtain corrosion current densities $\left(\mathrm{i}_{\text {corr }}\right.$ ), corrosion potential and corrosion rate [31]. The inhibition efficiency was calculated from the measured $\mathrm{i}_{\text {corr }}$ values using the following formulas [32][33].

Where:

$$
\text { Inhibition effeciency (\%IE) }=\frac{i_{\text {corr }}^{0}-i_{\text {corr }}^{1}}{i_{\text {corr }}^{0}} \times 100
$$

\footnotetext{
$\mathrm{i}_{\text {corr }}^{0}=$ Corrosion current density without inhibitor

$\mathrm{i}_{\text {co }}^{1}$

$\mathrm{i}_{\text {corr }}^{1}=$ Corrosion current density with inhibitor
}

All experiments were conducted at room temperature using $200 \mathrm{ml}$ of $1.0 \mathrm{M} \mathrm{H}_{2} \mathrm{SO}_{4}$ with different concentration of ADSE and ADPE inhibitors. Each experiment was repeated at least three times to check the reproducibility and the good reproducible results were reported. Prior to each experiment, the electrode was allowed to corrode freely for 20 min for potential stabilization [34][30].

In case of electrochemical impedance spectroscopy (EIS), experiments were carried out at open-circuit potential over a frequency range of $0.1 \mathrm{~Hz}-100 \mathrm{kHz}$ [35] using AC signals of amplitude $10 \mathrm{mV}$ peak to peak at the open circuit potential. The double layer capacitance $\left(\mathrm{C}_{\mathrm{dl}}\right)$ and charge transfer resistance $\left(R_{\mathrm{ct}}\right)$ values were derived from Nyquist plots which were obtained using the impedance data plotted in EIS analyser software. From the charge transfer resistance values, the inhibition efficiency of the inhibitor was calculated using the equation below [36];

$$
\text { Inhibition effeciency }(\% \mathrm{IE})=\frac{\mathrm{R}_{\mathrm{ct}}^{\mathrm{i}}-\mathrm{R}_{\mathrm{ct}}^{0}}{\mathrm{R}_{\mathrm{ct}}^{\mathrm{i}}} \times 100
$$

Where:

$\mathrm{R}_{\mathrm{ct}}^{\mathrm{i}}=$ Charge transfer resistance with inhibitor
$\mathrm{R}_{\mathrm{ct}}^{0}=$ Charge transfer resistance without inhibitor 


\subsection{Surface analysis}

The analysis of the morphology of MS surface was carried out using scanning electron microscopy (SEM) COXEM MODEL CX200 at room temperature. Images of MS coupons were taken after $3 \mathrm{~h}$ exposure time in $1.0 \mathrm{M} \mathrm{H}_{2} \mathrm{SO}_{4}$ with and without various concentrations of ADPE and ADSE

\subsection{Gravimetric Measurements}

\section{RESULTS AND DISCUSSION}

\subsubsection{Effect of Inhibitor Concentration}

The corrosion rate, surface coverage, and inhibition efficiency were calculated using equations (1), (2), and (3) and the data obtained are given in Table 1. It is clear from the results that the inhibition efficiency (\% IE) increases with increase in concentration of inhibitors. The observed behavior is due to the increase in adsorption and coverage on the mild steel surface which increase with concentration of the inhibitors .This shows the dependence of inhibiting effect of phytoconstituents of ADPE and ADSE. These extracts contain mixture of tannins, amino acids, alkaloids, proteins, flavonoids pigments which cause inhibitive action. So adsorption of these components on the metal surface reduced the surface area available for corrosion [37]. The adsorbed inhibitor molecules reduces the interaction between mild steel surface and aggressive medium by increasing the coverage of mild steel surface leading to a compact and coherent film on the surface of mild steel [38]. The degree of protection increases with the increasing surface coverage by adsorbed molecules [39].

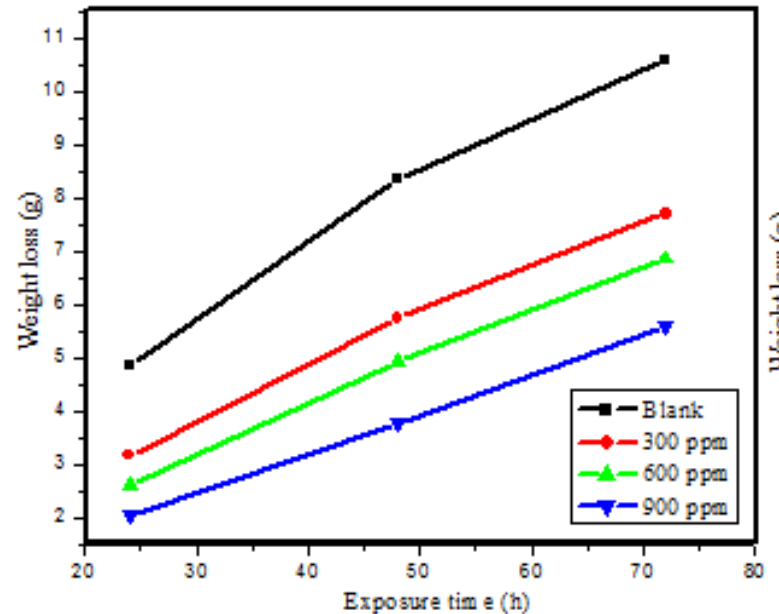

(a)

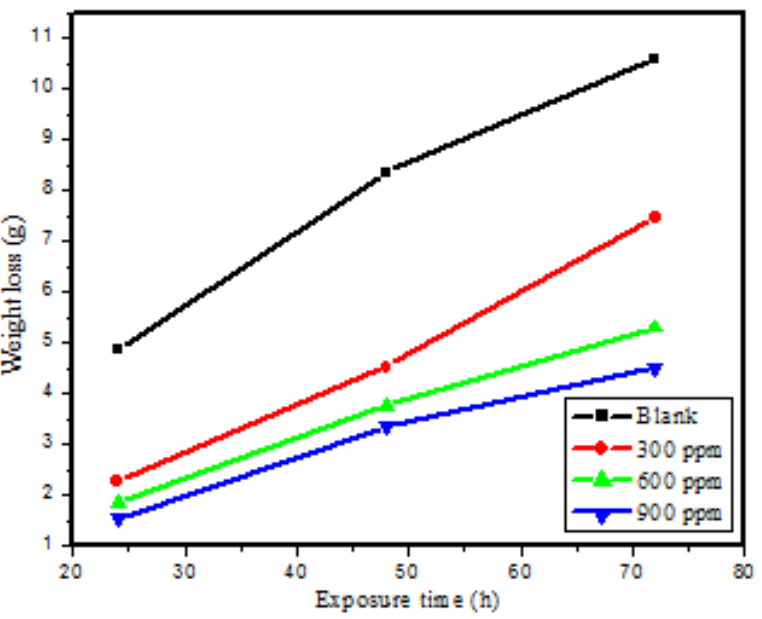

(b)

FIGURE 2: Plots of weight loss of MS against exposure time ADPE (a) and ADSE (b) in $1.0 \mathrm{M} \mathrm{H}_{2} \mathrm{SO}_{4}$.

TABLE 1: The gravimetric parameters for $\mathrm{MS}$ in $1.0 \mathrm{M} \mathrm{H}_{2} \mathrm{SO}_{4}$ in the presence and absence of Adansonia digitata extract with different concentrations at various time of immersion at $298 \mathrm{~K}$.

\begin{tabular}{|c|c|c|c|c|c|c|}
\hline Inhibitor & $\begin{array}{l}\text { Exposure } \\
\text { time (h) }\end{array}$ & $\begin{array}{ll}\begin{array}{l}\text { Conc. } \\
\text { inhibitor } \\
(\mathrm{ppm})\end{array} & \\
\end{array}$ & $\mathrm{W}_{1}(\mathrm{~g})$ & $\begin{array}{l}\text { Surface } \\
\text { coverage }\end{array}$ & $\begin{array}{l}\text { Inhibition } \\
\text { Efficiency }\end{array}$ & $\begin{array}{l}\begin{array}{l}\text { Corrosion } \\
\left(\text { mmpy) } E^{-3}\right.\end{array}\end{array}$ \\
\hline \multirow{11}{*}{ ADPE } & \multirow{4}{*}{24} & Blank & 4.862 & & & 56.440 \\
\hline & & 300 & 3.178 & 0.346 & 34.630 & 36.895 \\
\hline & & 600 & 2.607 & 0.464 & 46.380 & 30.263 \\
\hline & & 900 & 2.059 & 0.577 & 57.650 & 23.902 \\
\hline & \multirow{4}{*}{48} & Blank & 8.350 & & & 48.465 \\
\hline & & 300 & 5.755 & 0.311 & 31.080 & 33.402 \\
\hline & & 600 & 4.940 & 0.408 & 40.840 & 28.672 \\
\hline & & 900 & 3.775 & 0.548 & 54.790 & 21.911 \\
\hline & \multirow{3}{*}{72} & Blank & 10.576 & & & 40.923 \\
\hline & & 300 & 7.711 & 0.271 & 27.090 & 29.837 \\
\hline & & 600 & 6.865 & 0.351 & 35.090 & 26.563 \\
\hline
\end{tabular}


Corrosion Inhibitive and Adsorption Behaviour of Methanolic Extracts of Adansonia digitata ...

\begin{tabular}{|c|c|c|c|c|c|c|}
\hline & & 900 & 5.592 & 0.471 & 47.130 & 21.636 \\
\hline \multirow{12}{*}{ ADSE } & \multirow{4}{*}{24} & Blank & 4.862 & & & 56.440 \\
\hline & & 300 & 2.269 & 0.533 & 53.330 & 26.340 \\
\hline & & 600 & 1.858 & 0.618 & 61.780 & 21.571 \\
\hline & & 900 & 1.539 & 0.684 & 68.350 & 17.863 \\
\hline & \multirow{4}{*}{48} & Blank & 8.350 & & & 48.465 \\
\hline & & 300 & 4.522 & 0.458 & 45.840 & 26.249 \\
\hline & & 600 & 3.769 & 0.549 & 54.860 & 21.877 \\
\hline & & 900 & 3.365 & 0.597 & 59.700 & 19.531 \\
\hline & \multirow{4}{*}{72} & Blank & 10.576 & & & 40.923 \\
\hline & & 300 & 7.446 & 0.296 & 29.600 & 28.810 \\
\hline & & 600 & 5.304 & 0.499 & 49.850 & 20.523 \\
\hline & & 900 & 4.513 & 0.573 & 57.330 & 17.462 \\
\hline
\end{tabular}

The effect of inhibitor efficiency on the inhibitor concentrations is shown in Figure 2. Increasing the concentration of inhibitor from 300 to $900 \mathrm{ppm}$, increases \% IE from $34.63 \%$ to $57.65 \%$ for ADPE and $53.84 \%$ to $68.70 \%$ for ADSE. From these results ADSE exhibited high corrosion inhibitor efficiency (68.7\%) for MS.

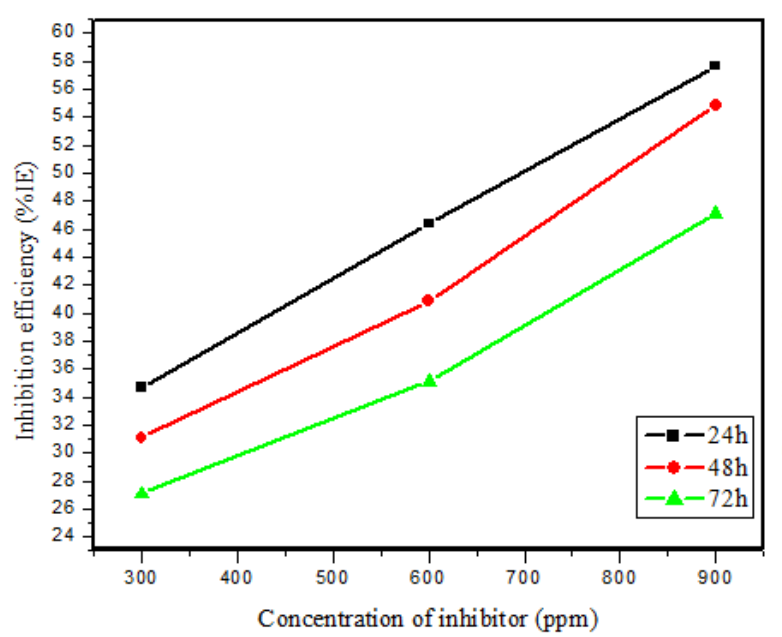

(a)

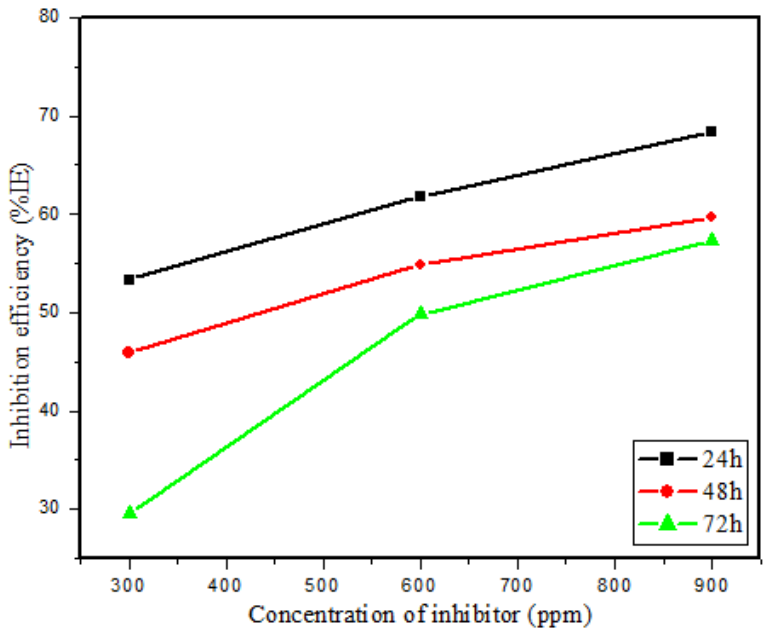

(b)

FIGURE 2: Inhibition efficiency plots against concentration of inhibitor ADPE (a) and ADSE (b) for MS corrosion in $1.0 \mathrm{M} \mathrm{H}_{2} \mathrm{SO}_{4}$.
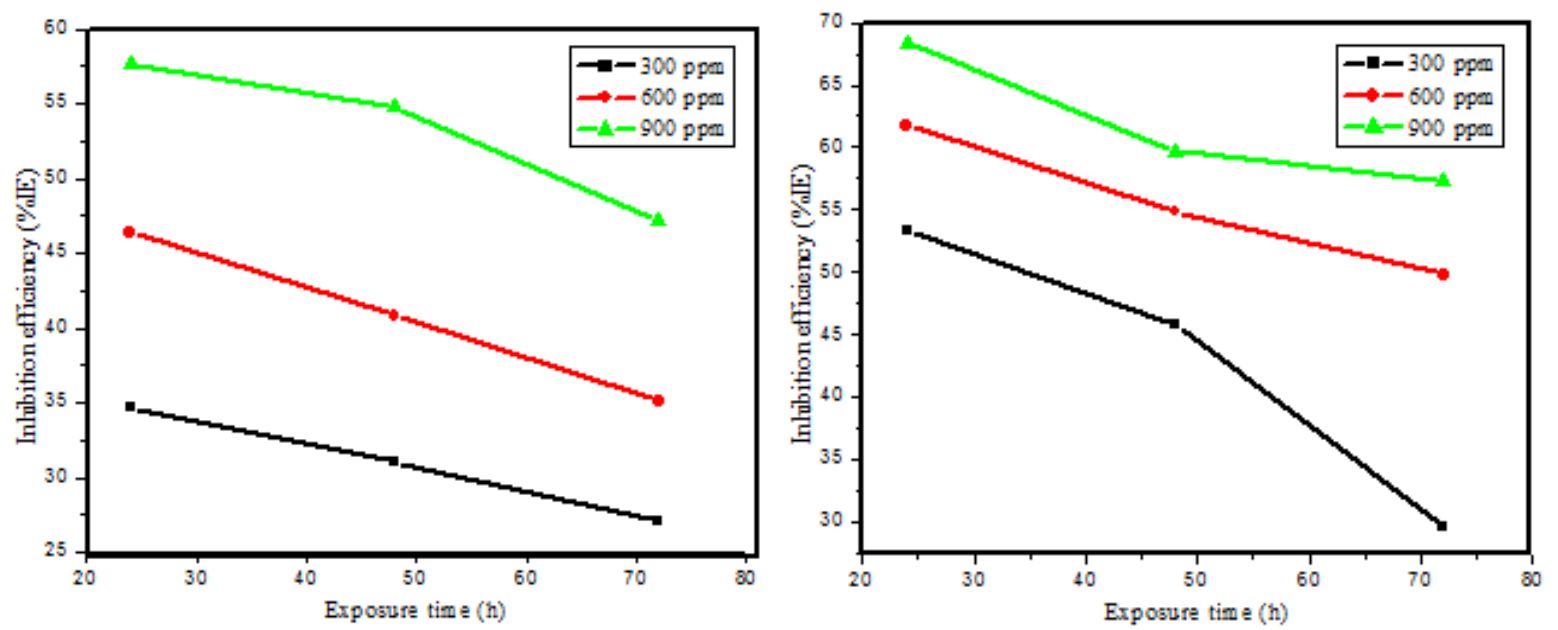

FIGURE 2: Inhibition efficiency plots against exposure time in ADPE (a) and ADSE (b) for MS corrosion in $1.0 \mathrm{M} \mathrm{H}_{2} \mathrm{SO}_{4}$. 


\subsubsection{Effect of Immersion Period}

The variation of weight loss with \% IE at various immersion periods is shown in Figure 3. It is obvious from the plots that the weight loss of MS decreases with immersion period which is possibly due to increased thickness of the adsorbed layer containing phytoconstituents and corrosion products at the MS surface.

The interaction of ADPE and ADSE with mild steel may be a result of the presence of polysaccharides and protein molecules in their structures. These molecules form a linkage with the metal surface by donating a lone pair of electrons. Inhibition efficiency decreases with immersion time in ADPE and increase with immersion time in ADSE. This effect may be due to the formation of insoluble film/corrosion product on the mild steel surface which lowers the interaction of the mild steel with the aggressive medium [40].

The decrease in corrosion rate with increasing inhibitor concentration, as shown in Figure 4 suggests that the inhibitor molecules act by adsorption on the metal surface. Consequently the increase of the inhibitor efficiency was attributed to the increase in surface coverage by extract molecules [41].

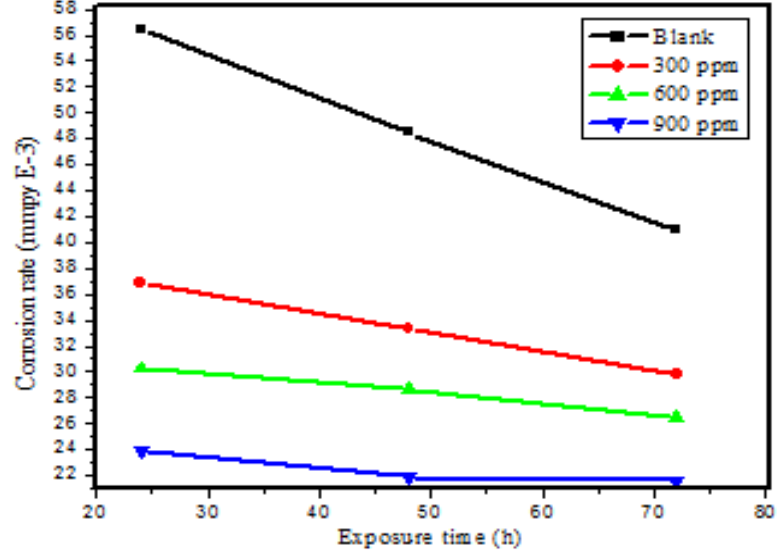

(a)

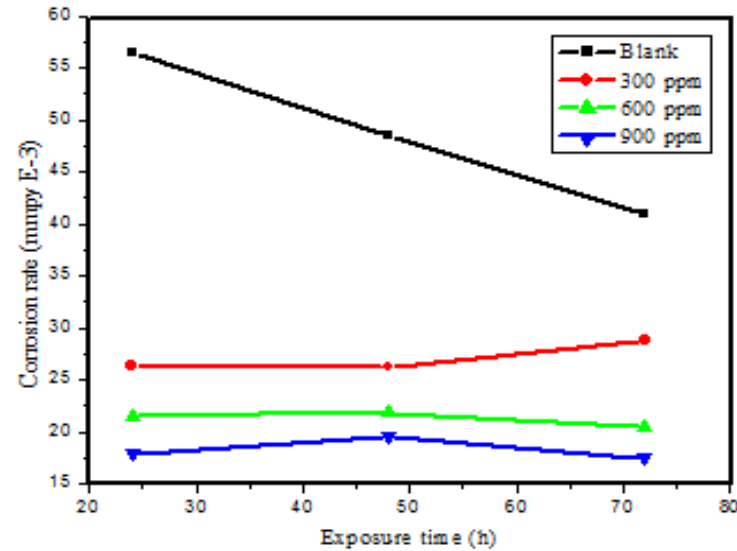

(b)

FIGURE 4: Corrosion rate plots for mild steel against exposure time with ADPE (a) and ADSE (b) in $1.0 \mathrm{M}$ $\mathrm{H}_{2} \mathrm{SO}_{4}$

\subsection{Potentiodynamic Polarisation Measurements}

Corrosion inhibition is achieved by altering the anodic process, cathodic process or both, which result in decreasing the rate of the corrosion process [42]. The corrosion current density ( $\left.\mathrm{I}_{\text {corr }}\right)$ and corrosion potential $\left(E_{\text {corr }}\right)$ were obtained from the intersection point of anodic and cathodic current curves in the Tafel plots. Potentiodynamic polarization parameters for the corrosion inhibition of mild steel in $1.0 \mathrm{M} \mathrm{H}_{2} \mathrm{SO}_{4}$ in the presence and absence of inhibitor are given in the Table 2. The corrosion current density $\mathrm{I}_{\text {corr }}$ values decreases markedly with increasing extract concentration from 552.70 to $247.26 \mathrm{~A} / \mathrm{cm}^{2}$ for ADPE, similarly for ADPE, $I_{\text {corr }}$ decreases from 552.70 to $185.97 \mathrm{~A} / \mathrm{cm}^{2}$. Tafel constants $b_{a}$ and $b_{c}$ markedly altered in presence of extract.

Polarization (Tafel) curves for MS in $1.0 \mathrm{M} \mathrm{H}_{2} \mathrm{SO}_{4}$ solution at room temperature in the absence and presence of different concentrations of inhibitors are given in Figure 5. From the figure it is obvious that the two extracts alter the electrochemical processes on mild steel by reducing the anodic reaction rates by reducing the corrosion current densities on both sides of the polarization curves. It can be concluded from Tafel slopes that the green inhibitor follows mixed type inhibition mode [43] as the shift in $\mathrm{E}_{\text {corr }}$ values for blank and inhibitor is less than $85 \mathrm{mV}$ even though polarisation appears to be under anodic control. The $\mathrm{E}_{\text {corr }}$ values varies from 445 $\mathrm{mV}$ to $422.95 \mathrm{mV}$ for ADPE and the shift in $\mathrm{E}_{\text {corr }}$ values for blank and ADSE inhibitor is less than $35 \mathrm{mV}$.

TABLE 2: Potentiodynamic polarization parameters for the corrosion inhibition of mild steel in $1.0 \mathrm{M} \mathrm{H}_{2} \mathrm{SO}_{4}$ in the presence and absence of inhibitors

\begin{tabular}{|l|l|l|l|l|l|l|l|}
\hline Inhibitor & $\begin{array}{l}\text { Conc. of } \\
\text { inhibitor } \\
(\mathrm{ppm})\end{array}$ & $\begin{array}{l}-\mathrm{E}_{\text {corr }} \\
(\mathrm{mV})\end{array}$ & $\begin{array}{l}\mathrm{I}_{\text {corr }} \\
\left(\mathrm{A} / \mathrm{cm}^{2}\right)\end{array}$ & $\begin{array}{l}\mathrm{b}_{\mathrm{a}} \\
(\mathrm{mV} / \mathrm{dec})\end{array}$ & $\begin{array}{l}\mathrm{b}_{\mathrm{c}} \\
(\mathrm{mV} / \mathrm{dec})\end{array}$ & $\begin{array}{l}\text { Inhibition } \\
\text { efficiency } \\
(\%)\end{array}$ & $\begin{array}{l}\text { Corrosion } \\
\text { rate } \\
(\mathrm{mm} / \text { year })\end{array}$ \\
\hline \multirow{5}{*}{ ADPE } & Blank & 445.26 & 552.70 & 82.084 & 117.600 & & 6.073 \\
\cline { 2 - 8 } & 300 & 426.12 & 434.68 & 50.227 & 83.155 & 21.354 & 3.692 \\
\cline { 2 - 8 } & 600 & 425.35 & 296.07 & 49.884 & 65.835 & 46.431 & 2.101 \\
\cline { 2 - 8 } & 900 & 422.95 & 247.26 & 261.280 & 139.770 & 55.263 & 1.712 \\
\hline \multirow{5}{*}{ ADSE } & Blank & 445.26 & 552.70 & 82.084 & 117.600 & & 6.073 \\
\cline { 2 - 8 } & 300 & 439.29 & 400.44 & 225.06 & 356.47 & 27.549 & 3.023 \\
\cline { 2 - 8 } & 600 & 416.65 & 240.79 & 107.510 & 51.473 & 56.434 & 2.030 \\
\cline { 2 - 8 } & 900 & 410.34 & 185.97 & 43.589 & 64.199 & 66.353 & 1.516 \\
\hline
\end{tabular}




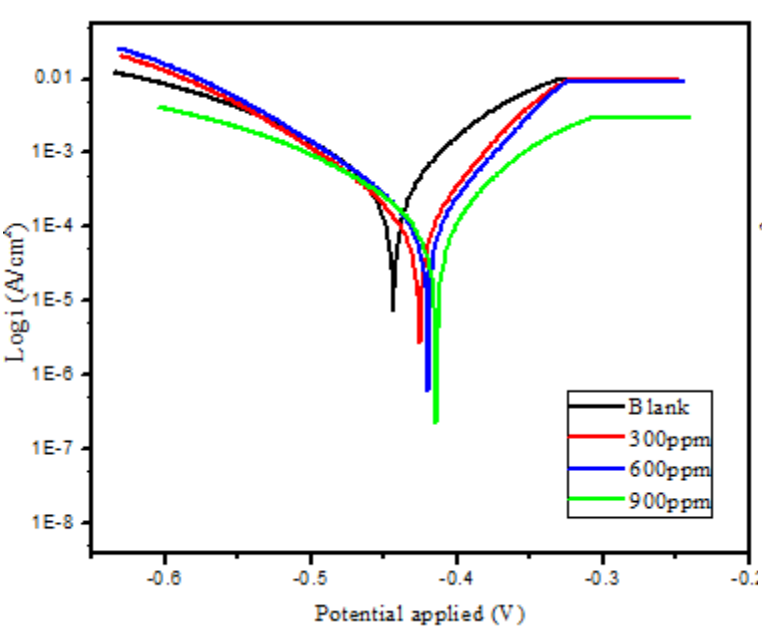

(a)

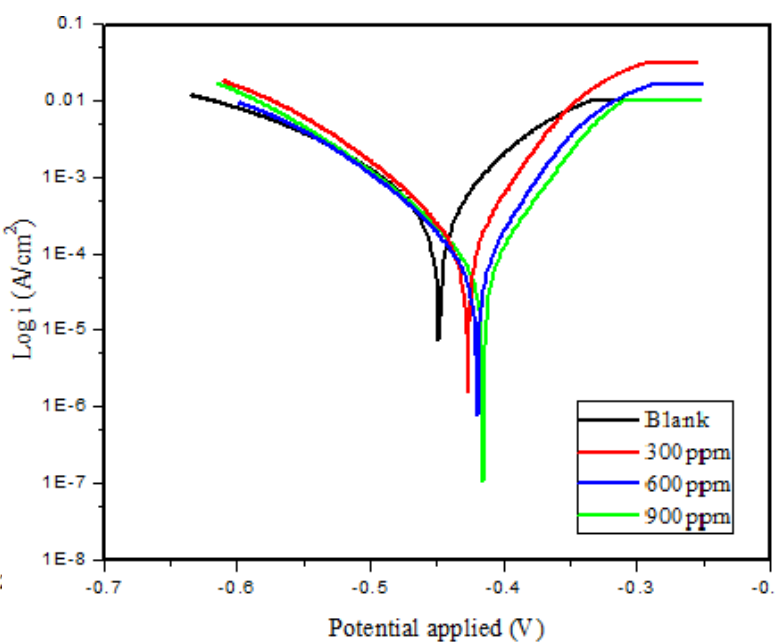

(b)

FIGURE 5: Tafel plots for MS corrosion in $1.0 \mathrm{M} \mathrm{H}_{2} \mathrm{SO}_{4}$ solution with different concentrations of inhibitor ADPE (a) and ADSE (b).

It is also seen form the plots that no significant change occurred for cathodic curves when compared with anodic curves which confirms that the inhibitor is more of anodic nature. The interaction between metal surface and lone pair of electrons of oxygen /nitrogen atoms of the extract decreases the anodic dissolution of mild steel due to adsorption.

\subsection{EIS Measurements}

The inhibition processes of ADPE and ADSE were also studied by electrochemical impedance spectroscopic (EIS) technique. The formation of film on metal surface is proved by impedance spectra. Basically corrosion process involves two steps, at first metal undergo oxidation and metal ions diffuse into the solution phase in the second step. Extract molecules get adsorbed at the surface of MS and there by prevent the metallic dissolution. Formation of the protective layer on the surface of mild steel boost the charge transfer resistance and diminish the double layer capacitance [44]. It is clear from the Nyquist's plots (Figure 6) that charge transfer resistance and inhibitor efficiency increase with inhibitor concentration.
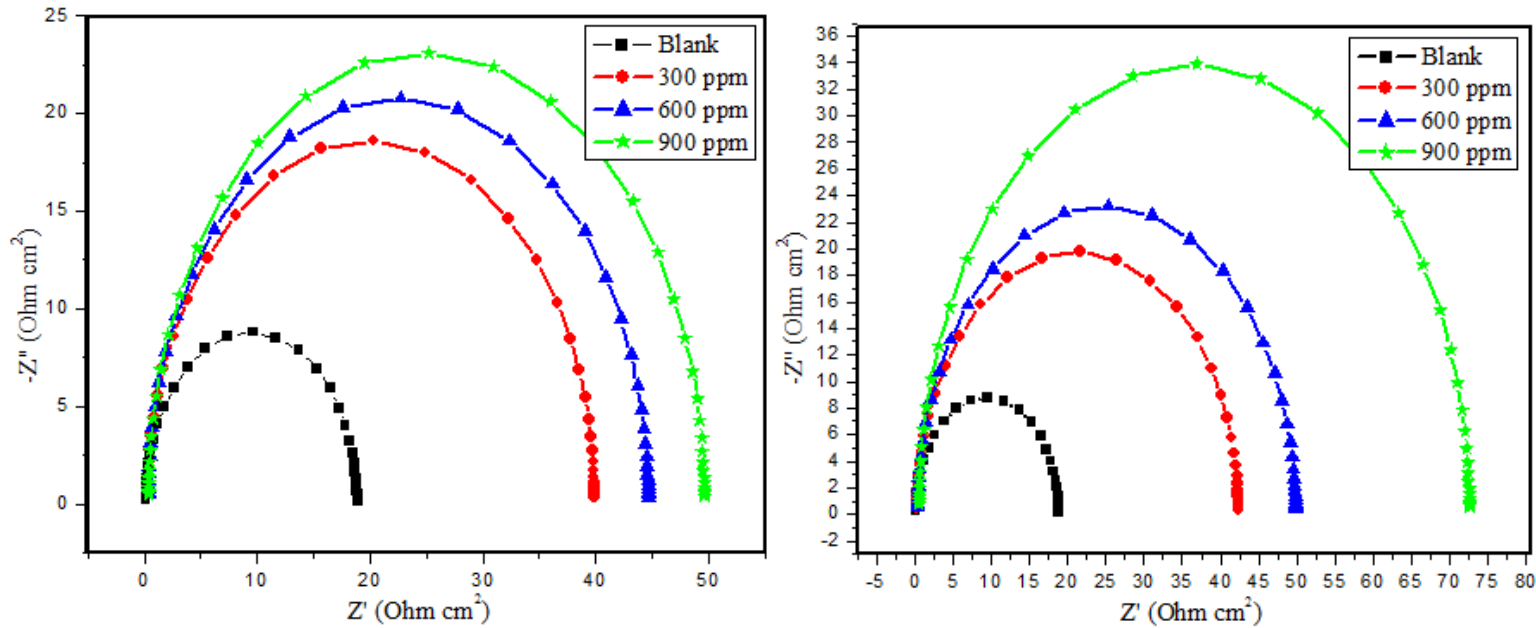

FIGURE 6: Nyquist plots (EIS) of mild steel in $1.0 \mathrm{M} \mathrm{H}_{2} \mathrm{SO}_{4}$ in absence and presence of different concentrations of inhibitor (ADPE left and ADSE right).

All impedance experimental data were tested in different circuit models to get excellent fit with lower error which agreed with the circuit Figure 7 . The impedance parameters such as solution resistance $\left(R_{s}\right)$, charge transfer resistance $\left(\mathrm{R}_{\mathrm{ct}}\right)$ and double-layer capacitance $\left(\mathrm{C}_{\mathrm{dl}}\right)$ were used to calculate the inhibition efficiency using the formula (5), 


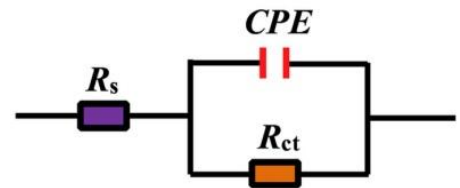

FIGURE 7: Equivalent circuit model used to fit the impedance spectral data.

The diameter of Nyquist plots increased on increasing the concentration of ADPE and ADSE which shows that these extracts strengthens the inhibitive film.

TABLE 3. EIS data for mild steel in $1.0 \mathrm{M} \mathrm{H}_{2} \mathrm{SO}_{4}$ with various concentration of inhibitors

\begin{tabular}{|c|c|c|c|c|c|}
\hline Inhibitor & $\begin{array}{ll}\text { Conc. } & \text { Of } \\
\text { inhibitor } & \\
(\mathrm{ppm}) & \\
\end{array}$ & $\begin{array}{l}\mathrm{C}_{\mathrm{dl}} \\
\left(\mu \mathrm{Fcm}^{-2}\right)\end{array}$ & $\begin{array}{l}\mathrm{R}_{\mathrm{s}} \\
\left(\Omega \mathrm{cm}^{2}\right)\end{array}$ & $\begin{array}{l}\mathrm{R}_{\mathrm{ct}} \\
\left(\Omega \mathrm{cm}^{2}\right)\end{array}$ & $\begin{array}{l}\text { Inhibition } \\
\text { efficiency }(\%)\end{array}$ \\
\hline \multirow{4}{*}{ ADPE } & Blank & 93.478 & 0.114 & 15.254 & \\
\hline & 300 & 74.219 & 0.143 & 19.203 & 20.585 \\
\hline & 600 & 51.983 & 0.204 & 27.426 & 44.396 \\
\hline & 900 & 42.009 & 0.253 & 33.945 & 55.074 \\
\hline \multirow{4}{*}{ ADSE } & Blank & 93.478 & 0.114 & 15.254 & \\
\hline & 300 & 65.998 & 0.161 & 21.590 & 29.365 \\
\hline & 600 & 39.613 & 0.268 & 36.005 & 57.645 \\
\hline & 900 & 31.246 & 0.339 & 45.605 & 66.561 \\
\hline
\end{tabular}

From the impedance data given in Table 3, the charge transfer resistance $\left(R_{c t}\right)$ values increase with inhibitor concentration which shows that a charge transfer process mainly controlling the corrosion of mild steel in acidic media. The double layer capacitance $\left(\mathrm{C}_{\mathrm{dl}}\right)$ was found to vary from $93.478 \mu \mathrm{Fcm}^{-2}$ for blank solution to $42.009 \mu \mathrm{Fcm}^{-2}$ for inhibited solution. The values of double layer capacitance decrease with increase of inhibitor concentration due to the adsorption of the inhibitor on the metal surface leading to the formation of film or complex from acidic solution [45].

The decrease in $\mathrm{C}_{\mathrm{dl}}$ values generally related to the adsorption of organic molecules on the metal surface and then leads to a decrease in the local dielectric constant and/or an increase in the thickness of the electrical double layer. The inhibition efficiency (\% IE) determined by three different methods (weight loss measurements, polarization studies and electrochemical impedance spectroscopy), as a function of concentration of the extracts show good agreement.

\subsection{Adsorption isotherms}

Adsorption isotherm is used to provide useful insight into the mechanism of corrosion inhibition. The experimental data from weight loss measurements were applied to different adsorption isotherm equations to fit the values of surface coverage $(\theta)$ to get an isotherm with higher regression coefficient. Most commonly applied adsorption isotherms are Temkin, Langmuir and Frumkin isotherms [46][47]. In Langmuir isotherm it is assumed that all sites have equal possibility for adsorption and it is not affected by activity at nearby sites [48]. . Langmuir isotherm was tested by the plot between $\mathrm{C} / \theta$ and $\mathrm{C}$ according to equation below;

$$
\frac{C}{\theta}=\frac{1}{K_{a d s}}+C
$$

TABLE 4: Langmuir adsorption isotherm data for mild steel in $1.0 \mathrm{M} \mathrm{H}_{2} \mathrm{SO}_{4}$ for ADPE and ADSE

\begin{tabular}{|c|c|c|c|c|}
\hline Media & $\begin{array}{l}\text { Inhibitor } \\
\text { concentration } \\
(\mathrm{g} / \mathrm{L})\end{array}$ & $\begin{array}{l}\text { Surface } \\
\text { coverage }(\theta)\end{array}$ & $\mathrm{C} / \theta$ & $\mathrm{R}^{2}$ \\
\hline \multirow{3}{*}{$\begin{array}{l}1.0 \mathrm{M} \mathrm{H}_{2} \mathrm{SO}_{4}+ \\
\text { ADPE }\end{array}$} & 0.3 & 0.4463 & 0.672 & \multirow{3}{*}{0.9997} \\
\hline & 0.6 & 0.5438 & 1.103 & \\
\hline & 0.9 & 0.5965 & 1.509 & \\
\hline \multirow{3}{*}{$\begin{array}{l}1.0 \mathrm{M} \mathrm{H}_{2} \mathrm{SO}_{4}+ \\
\mathrm{ADSE}\end{array}$} & 0.3 & 0.6333 & 0.474 & \multirow{3}{*}{0.9987} \\
\hline & 0.6 & 0.6878 & 0.872 & \\
\hline & 0.9 & 0.7435 & 1.210 & \\
\hline
\end{tabular}




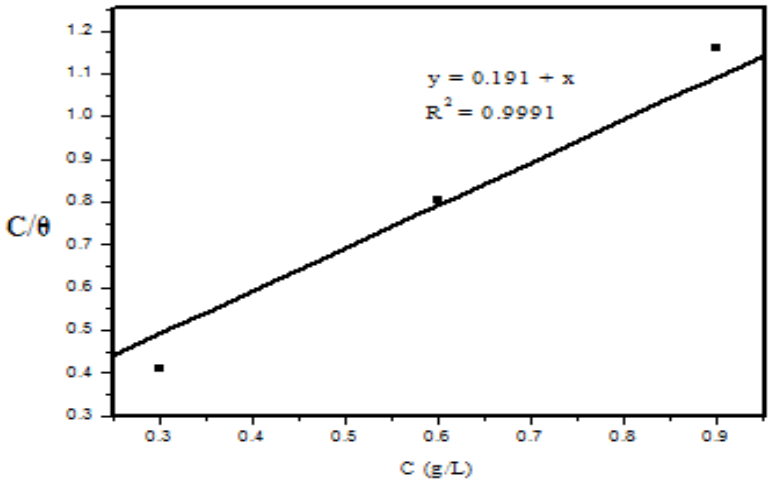

(a)

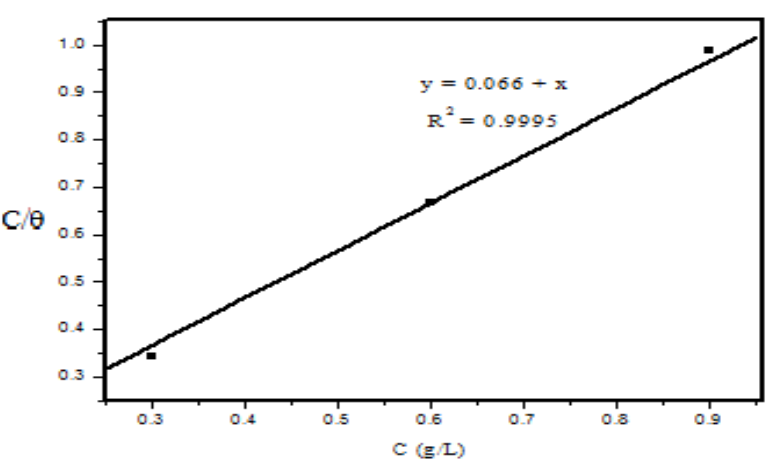

(b)

FIGURE 8: Langmuir adsorption isotherm plot for mild steel in $1.0 \mathrm{M} \mathrm{H}_{2} \mathrm{SO}_{4}$ with ADPE (a) and ADSE (b) at $298 \mathrm{~K}$

Langmuir isotherm (Figure 8) gave straight line with the slope of the unit, where the regression coefficient $\mathrm{R}^{2}$ values for Langmuir isotherm were 0.9996 and 0.9998 for ADPE and ADSE respectively. Adsorption depends on chemical composition of extract which showed the presence of various compounds like flavonoids, terpenoids, phytosterols, amino acids, carbohydrates, lipids, vitamins. These inhibitors obey the Langmuir adsorption isotherm [21] [20].

This explains the monolayer formation of the inhibitor on the surface of MS [46]. Thermodynamic parameters (Table 5) for the adsorption of both extracts on the MS are calculated using the equation given below,

$$
\Delta \mathrm{G}_{\mathrm{ads}}=-\mathrm{RT} \ln \left(55.5 \mathrm{~K}_{\mathrm{ads}}\right)
$$

TABLE 5: Langmuir thermodynamic parameters for ADPE and ADSE

\begin{tabular}{|l|l|l|}
\hline Inhibitor & $\mathbf{K}_{\text {ads }}$ & $\Delta \mathbf{G}_{\text {ads }}\left(\mathbf{k J m o l}^{-1}\right)$ \\
\hline ADPE & 2.732 & -12.441 \\
\hline ADSE & 3.330 & -12.932 \\
\hline
\end{tabular}

Generally, it is accepted that when $\Delta \mathrm{G}_{\mathrm{ads}}$ values are about $20 \mathrm{~kJ} / \mathrm{mol}$ or lower, adsorption is regarded as physisorption. For this, the inhibition is said to acts through electrostatic interaction between the charged molecules and the charged metal. Also, for the values around $40 \mathrm{~kJ} / \mathrm{mol}$ or higher, the interactions are seen as chemisorption in which charge sharing or a charge transfer from the inhibitor molecules to the metal surface occurs to form covalent bond. In the present study the values of free energy of adsorption for both ADPE and ADSE were around - $12.441 \mathrm{~kJ} \mathrm{~mol}^{-1}$ and $-12.932 \mathrm{~kJ} \mathrm{~mol}^{-1}$ respectively. This means both inhibitors are physically adsorbed on the surface of mild steel.

\subsection{SEM analysis}

SEM images were recorded to know the surface deterioration before and after MS corrosion on exposure to the $1.0 \mathrm{M}$ $\mathrm{H}_{2} \mathrm{SO}_{4}$ solution in the absence and presence of ADPE and ADSE inhibitors. SEM images for MS surface before immersion and after immersion in $1.0 \mathrm{M} \mathrm{H}_{2} \mathrm{SO}_{4}$ without inhibitor are shown in Figure 9. The SEM images show that the mild steel was heavily corroded in $1.0 \mathrm{M} \mathrm{H}_{2} \mathrm{SO}_{4}$ as shown in Figure 9 (b) without inhibitors where as in the presence of inhibitors ADPE and ADSE as the surface conditions were comparatively better as seen in Figure 10 (a) and 10 (b) respectively.

This shows that the inhibitor molecules hinder the dissolution of mild steel by forming surface adsorbed layer and thereby reducing the corrosion rate. It also confirms that the inhibitors effectively control the corrosion phenomenon by blocking the active corrosion causing sites on the mild steel surface. Metal surface was highly covered with the protective layer formed by the green inhibitor which prevents the metal from further attack of acid media [43].

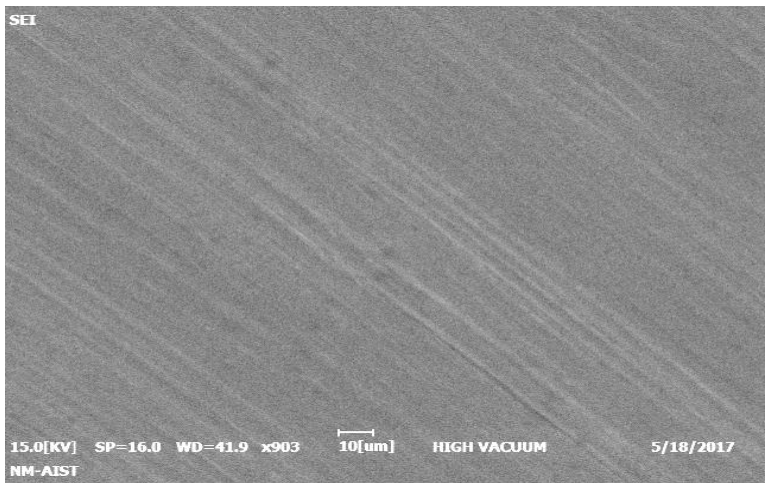

(a)

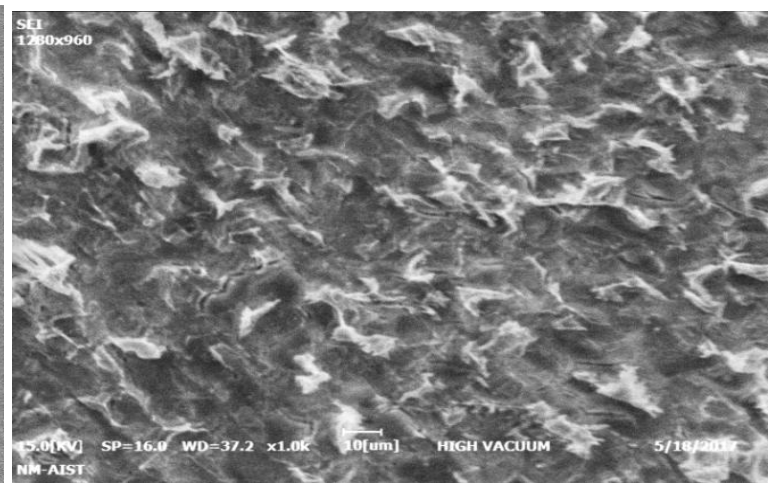

(b)

FIGURE 9: SEM images for mild steel surface before immersion (a) and after immersion in $1.0 \mathrm{M} \mathrm{H}_{2} \mathrm{SO}_{4}$ without inhibitor (b). 


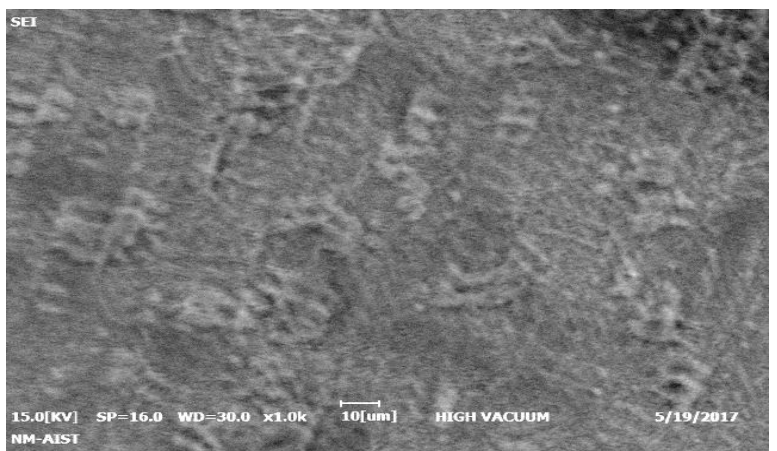

(a)

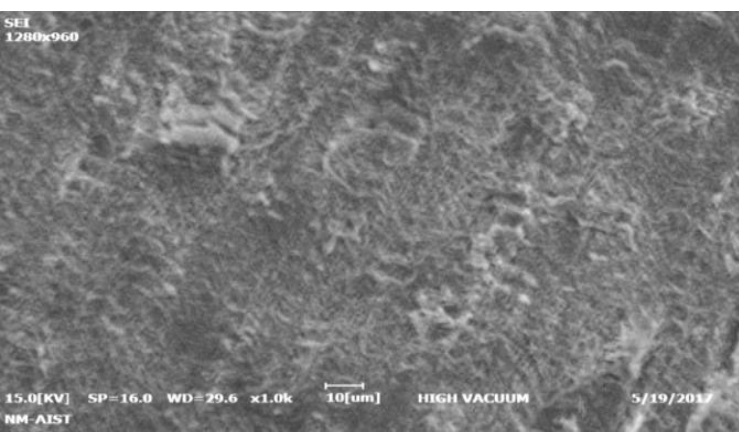

(b)

FIGURE 10: SEM images for mild steel surface after immersion in $1.0 \mathrm{M} \mathrm{H}_{2} \mathrm{SO}_{4}$ with inhibitors ADPE (a) and ADSE (b).

It is observed from the Figure 10 that the surface deterioration is more in case of MS exposed to ADPE in acidic solution than that exposed to ADSE which could be attributed to the presence of higher proportions of active phytoconstituents in seeds than in pulp of baobab fruits.

\section{CONCLUSION}

The seeds (ADSE) and pulp (ADPE) extracts from baobab (Adansonia digitata) fruits proved to be effective green and ecofriendly inhibitors for mild steel corrosion in $1.0 \mathrm{M} \mathrm{H}_{2} \mathrm{SO}_{4}$ medium. The gravimetric analysis revealed that both inhibitors ADSE and ADPE found to follow mixed type inhibition mode even though anodic reaction influence was predominant.

The inhibitor efficiency of extracts was found increase with increase in inhibitor concentration. ADSE exhibited higher $\%$ IE compared to that of ADPE which could be attributed to the presence of higher percentage of active compound in baobab seeds. Potentiodynamic polaristaion plots revealed that the corrosion current density was least for higher concentration of inhibitors. Corrosion rate of MS was found to decrease with increase in extract concentrations.

This inhibitor obeys the Langmuir adsorption isotherm. Adsorption was effective due to the presence of various active compounds like flavonoids, terpenoids, phytosterols, amino acids, carbohydrates, lipids and vitamins in the extracts. The EIS study shows that Charge transfer resistance $\left(R_{c t}\right)$ increases and double layer capacitance $\left(C_{d 1}\right)$ decreases with the increase in the inhibitor concentrations. The surface analysis by SEM confirms the presence of protective film on MS surface in the presence of inhibitors.

\section{Acknowledgements}

The authors are grateful to the University of Dodoma, Dodoma, for providing funds towards this research project and thankful to the Nelson Mandela Institute of Science and Technology, Arusha, for providing the Instrumental facilities.

\section{REFERENCES}

[1] D. Senthil, R. Saratha, and R. Vasantha, "Corrosion inhibition of mild steel in hydrochloric acid medium using plant extracts - a succinct review ISSN : 2278 - 7798 International Journal of Scienc,” vol. 5, no. 12, pp. 3324-3340, 2016.

[2] P. M. Ejikeme, S. G. Umana, M. C. Menkiti, and O. D. Onukwuli, "Inhibition of Mild Steel and Aluminium Corrosion in 1M H 2 SO 4 by Leaves Extract of African Breadfruit," vol. 5, no. 1, pp. 14-23, 2015.

[3] G. Ji, P. Dwivedi, S. Sundaram, and R. Prakash, "Inhibitive E ff ect of Chlorophytum borivilianum Root Extract on Mild Steel Corrosion in $\mathrm{HCl}$ and $\mathrm{H} 2 \mathrm{SO} 4$ Solutions," Ind. Eng. Chem. Res., vol. 52, pp. 10673-10681, 2013.

[4] N. S. Patel, S. Jauhariand, G. N. Mehta, S. S. Al-Deyab, I. Warad, and B. Hammouti, "Mild Steel Corrosion Inhibition by Various Plant Extracts in 0.5 M Sulphuric acid," Int. J. Electrochem. Sci, vol. 8, pp. 2635-2655, 2013.

[5] H. Olasehinde, E. F, Olusegun S. J. , Adesina, A. S.1, Omogbehin, S. A, Momoh-Yahayah, "Inhibitory Action of Nicotiana tabacum Extracts on the Corrosion of Mild Steel in $\mathrm{HCl}$ : Adsorption and Thermodynamics Study," Nat. Sci., vol. 11, no. 1, pp. $83-90,2013$

[6] R. Saratha, N. Kasthuri, P. Thilagavathy, and others, "Environment friendly acid corrosion inhibition of mild steel by Ricinus communis Leaves," Der Pharma Chem., vol. 1, no. 2, pp. 249-257, 2009.

[7] P. C. Okafor, M. E. Ikpi, I. E. Uwah, E. E. Ebenso, U. J. Ekpe, and S. A. Umoren, "Inhibitory action of Phyllanthus amarus extracts on the corrosion of mild steel in acidic media," Corros. Sci., vol. 50, no. 8, pp. 2310-2317, 2008.

[8] A. S. Abdulrahman, M. Ismail, and M. S. Hussain, "Inhibition of Corrosion of Mild Steel in Hydrochloric Acid by Bambusa Arundinacea Preparation of Plant Extracts," Int. Rev. Mech. Eng., vol. 5, no. 1, pp. 59-63, 2007.

[9] A. Singh, V. K. Singh, and M. A. Quraishi, "Inhibition of Mild Steel Corrosion in HCl Solution Using Pipali (Piper longum) Fruit Extract," Arab. J. Sci. Eng., vol. 38, no. 1, pp. 85-97, 2013.

[10] P. Raja, A. Rahim, H. Osman, and K. Awang, "Inhibitory Effect of Kopsia Singapurensis Extract on the Corrosion Behavior ofMild Steel in AcidMedia," Acta Physico-Chimica Sin., vol. 26, no. 8, pp. 2171-2176, 2010.

[11] M. Chigondo and F. Chigondo, "Recent Natural Corrosion Inhibitors for Mild Steel : An Overview," Hindawi Publ. Corp. J. Chem., vol. 2016, 2016.

[12] J. Buchweishaija, "Phytochemicals as green corrosion inhibitors in various corrosive media : A review," 2008.

[13] P. B. Raja and M. G. Sethuraman, "Natural products as corrosion inhibitor for metals in corrosive media - A review," Mater. Lett., vol. 62, pp. 113-116, 2008.

[14] J. Buchweishaija and G. S. Mhinzi, "Natural Products as a Source of Environmentally Friendly Corrosion Inhibitors: The Case of Gum Exudate from Acacia seyal var. seyal," Port. Electrochim. Acta, vol. 26, no. 3, pp. 257-265, 2007. 
[15] B. Sanyal, "Organic compounds as corrosion inhibitors in different environments -- A review," Prog. Org. Coatings, vol. 9, pp. $165-236,1981$.

[16] G. Pankaj and J. Gargi, "Corrosion Inhibition by Aloe barbadensis ( aloe vera ) extract as Green Inhibitor for Mild Steel in HNO 3,”Int. J. Sci. Res. Rev., vol. 3, no. 4, pp. 72-83, 2014.

[17] A. Singh, A. Kumar, and T. Pramanik, "A Theoretical Approach to the Study of Some Plant Extracts as Green Corrosion Inhibitor for Mild Steel in HCl Solution," pp. 1-7, 2013.

[18] S. K. Shukla and M. A. Quraishi, "Cefalexin drug: A new and efficient corrosion inhibitor for mild steel in hydrochloric acid solution," Mater. Chem. Phys., vol. 120, pp. 142-147, 2010.

[19] O. State, "Effects of different drying methods on the nutritional and quality attributes of baobab leaves ( Adansonia digitata ). * Department of Food Science and Engineering," Agric. Biol. J. North Am., vol. 5, no. 3, pp. 104-108, 2014.

[20] M. Sidibe, J. T. Williams, A. Hughes, N. Haq, and R. W. Smith, Baobab. Adansonia digitata. International Centre for Underutilised Crops, 2002.

[21] V. Namratha and P. Sahithi, "Baobab : A Review about “ The Tree of Life, ," Int. J. Adv. Herb. Sci. Technol., vol. 1, no. 1, pp. 20 26, 2015.

[22] P. Group, "Baobab Tree ( Adansonia digitata L ) Parts: Nutrition, Applications in Food and Uses in Ethno-medicine - A Review," vol. 1, no. 3, 2014.

[23] A. a. Shahat, "Procyanidins from Adansonia digitata .," Pharm. Biol., vol. 44, no. 6, pp. 445-450, 2006.

[24] B. Sultana, F. Anwar, and M. Ashraf, "Effect of extraction solvent/technique on the antioxidant activity of selected medicinal plant extracts," Molecules, vol. 14, no. 6, pp. 2167-2180, 2009.

[25] R. P. Farooq Anwar, "Effect of solvents extraction on total phenolics and antioxidant activity of extracts from flaxseed ( linum usitatissimum 1.)," 2012.

[26] K. K. Anupama, K. Ramya, and A. Joseph, "Electrochemical and computational aspects of surface interaction and corrosion inhibition of mild steel in hydrochloric acid by Phyllanthus amarus leaf extract (PAE)," J. Mol. Liq., vol. 216, pp. 146-155, 2016.

[27] K. Krishnaveni, J. Ravichandran, and A. Selvaraj, "Effect of Morinda tinctoria leaves extract on the corrosion inhibition of mild steel in acid medium," Acta Metall. Sin. (English Lett., vol. 26, no. 3, pp. 321-327, 2013.

[28] R. Rajalakshmi, S. Subhashini, S. Leelavathi, and R. F. Mary, "Efficacy of sprouted seed extracts of Phaseolus aureus on the corrosion inhibition of mild steel in 1m HCl," Orient. J. Chem., vol. 24, no. 3, pp. 1085-1090, 2008.

[29] M. H. Hussin, A. A. Rahim, M. N. Mohamad Ibrahim, and N. Brosse, "The capability of ultrafiltrated alkaline and organosolv oil palm (Elaeis guineensis) fronds lignin as green corrosion inhibitor for mild steel in $0.5 \mathrm{M} \mathrm{HCl}$ solution," Meas. J. Int. Meas. Confed., vol. 78, pp. 90-103, 2016.

[30] A. Singh, V. K. Singh, and M. A. Quraishi, "Aqueous extract of kalmegh (andrographis paniculata) leaves as green inhibitor for mild steel in hydrochloric acid solution," Int. J. Corros., vol. 2010, 2010.

[31] A. K. Singh, S. Mohapatra, and B. Pani, "Corrosion inhibition effect of Aloe Vera gel: Gravimetric and electrochemical study," $J$. Ind. Eng. Chem., vol. 33, pp. 288-297, 2016.

[32] R. S. Mayanglambam, V. Sharma, and G. Singh, "Musa Paradisiaca Extract as a Green Inhibitor for Corrosion of Mild Steel in 0.5 M Sulphuric Acid Solution,” Port. Electrochim. Acta, vol. 29, no. 6, pp. 405-417, 2011.

[33] A. K. Satapathy, G. Gunasekaran, S. C. Sahoo, K. Amit, and P. V. Rodrigues, "Corrosion inhibition by Justicia gendarussa plant extract in hydrochloric acid solution," Corros. Sci., vol. 51, no. 12, pp. 2848-2856, 2009.

[34] M. Chevalier, F. Robert, N. Amusant, M. Traisnel, C. Roos, and M. Lebrini, "Enhanced corrosion resistance of mild steel in $1 \mathrm{M}$ hydrochloric acid solution by alkaloids extract from Aniba rosaeodora plant: Electrochemical, phytochemical and XPS studies," Electrochim. Acta, vol. 131, pp. 96-105, 2014.

[35] H. Cang, W. Shi, J. Shao, and Q. Xu, "Study of Stevia rebaudiana leaves as green corrosion inhibitor for mild steel in sulphuric acid by electrochemical techniques," Int. J. Electrochem. Sci., vol. 7, no. 4, pp. 3726-3736, 2012.

[36] M. Prabakaran, S. H. Kim, K. Kalaiselvi, V. Hemapriya, and I. M. Chung, "Highly efficient Ligularia fischeri green extract for the protection against corrosion of mild steel in acidic medium: Electrochemical and spectroscopic investigations," J. Taiwan Inst. Chem. Eng., vol. 59, pp. 553-562, 2016.

[37] E. E. Oguzie, "Inhibition of acid corrosion of mild steel by Telfaria occidentalis extract," Pigment Resin Technol., vol. 34, no. 6, pp. 321-326, 2005.

[38] E. Cor-, "Standard Practice for Laboratory Immersion Corrosion Testing of Metals 1," vol. i, no. Reapproved, 2004.

[39] K. Kanagavalli, "Caesalpinia pulcherrima as corrosion inhibitor for mild steel in Acid medium," Int. J. Sci. Eng. Res., vol. 5, no. 10, pp. 1411-1416, 2014.

[40] R. A.-M. Saedah and S. R. Al-Mhyawi, "Inhibition of mild steel corrosion using Juniperus plants as green inhibitior," African J. Pure Appl. Chem., vol. 8, no. 1, pp. 9-22, 2014.

[41] H. Cang, Z. Fei, J. Shao, W. Shi, and Q. Xu, "Corrosion inhibition of mild steel by Aloes extract in HCL solution medium," Int. J. Electrochem. Sci., vol. 8, no. 1, pp. 720-734, 2013.

[42] M. Manickam, D. Sivakumar, B. Thirumalairaj, and M. Jaganathan, "Corrosion Inhibition of Mild Steel in $1 \mathrm{~mol} \mathrm{~L}-1 \mathrm{HCl}$ Using Gum Exudates of Azadirachta indica," vol. 2016, 2016.

[43] B. Raja and M. G. Sethuraman, "Solanum Tuberosum as an Inhibitor of Mild Steel Corrosion in Acid Media," vol. 28, no. 1, pp. 77-84, 2009

[44] J. Bhawsar, P. K. Jain, and P. Jain, "Experimental and computational studies of Nicotiana tabacum leaves extract as green corrosion inhibitor for mild steel in acidic medium," Alexandria Eng. J., vol. 54, no. 3, pp. 769-775, 2015.

[45] M. Znini et al., "Green approach to corrosion inhibition of mild steel by essential oil leaves of Asteriscus Graveolens (Forssk.) in sulphuric acid medium,” Int. J. Electrochem. Sci., vol. 7, no. 5, pp. 3959-3981, 2012.

[46] H. Z. Alkhathlan, M. Khan, M. M. S. Abdullah, A. M. Al-Mayouf, A. A. Mousa, and Z. A. M. Al-Othman, "Launaea nudicaulis as a source of new and efficient green corrosion inhibitor for mild steel in acidic medium: A comparative study of two solvent extracts," Int. J. Electrochem. Sci., vol. 9, no. 2, pp. 870-889, 2014.

[47] M. Ramananda Singh, P. Gupta, and K. Gupta, "The litchi (Litchi Chinensis) peels extract as a potential green inhibitor in prevention of corrosion of mild steel in 0.5M H2SO4 solution," Arab. J. Chem., pp. 0-6, 2013.

[48] S. K. Shukla, P. Dwivedi, S. Sundaram, and E. E. Ebenso, "Green Capsicum annuum Fruit Extract for Inhibition of Mild Steel Corrosion in Hydrochloric acid solution," Int.J.Electrochem.Sci, vol. 7, pp. 12146-12158, 2012.

Petro Novert Karungamye. "Methanolic Extracts of Adansonia digitata (Baobab) Fruit Pulp and Seeds as Potential Green Inhibitors for Mild Steel Corrosion in $1.0 \mathrm{M} \mathrm{H}_{2} \mathrm{SO}_{4}$ solution." IOSR Journal of Applied Chemistry (IOSR-JAC) 10.7 (2017): 64-74.

DOI: 10.9790/5736-1007016474 www.iosrjournals.org

74 |Page 